\title{
Albania's Central Bank's Monetary Policy Has Failed
}

\author{
Alqi Naqellari \\ Lecturer, \\ Mediterranean University of Albania, \\ Albania \\ Sokol Paçukaj \\ Aleksander Moisiu University, \\ Albania
}

\begin{abstract}
The subject of this paper will be the Central Bank's monetary policy in terms of the Albanian monetary market. Its purpose will be to determine the effects of monetary policy, its consequences on some of the key macroeconomic indicators. From the analysis of data, it was found that the Central Bank's policy, which has its main objective, "achieving and preserving the level of prices", is applied in the conditions of an unequal monetary market, because the money market is almost divided equal to 50/50 between currency and local currency (All). These main internal factors, and other external factors, have made the monetary policy applied by the Central Bank to have no impact or have negative consequences on key macroeconomic indicators. Central Bank monetary policy is currently smothered. Some of the negative consequences are: the decline of the impact on the inflation indicator, the transition of the Albanian economy to the "liquid trap", the change in the structure of deposit usage in favor of debt instruments, decrease of deposits in total and deposits in lek, the decline in purchasing power of deposits, the reduction of credit and the change of their structure, consequently the reduction of productive investments, euro depreciation, trade deficit growth, etc. Under these conditions, only fiscal policies have an impact. In order for the Central Bank's policies to become effective, with concrete implications on the economic indicators, fundamental changes need to be made. First, change its main objective by having the main objective "currency stability and economic growth" secondly, to establish a fully state-owned commercial bank in order to support the monetary policies and key sectors of the economy. The methods used in this paper are the method of description, comparison, analysis and synthesis, statistical methods etc.
\end{abstract}

Keywords. Monetary Policy, Fiscal Policy, Inflation, GDP, Trade Balance, exchange rates, loans, deposits, effectiveness

\section{Introduction}

In Albania until 1990 there was a single monetary system. The Albanian State Bank was the only bank to carry out all its functions; drafted monetary policies, issued currency, 


\section{Journal of International Cooperation and Development}

www.richtmann.org/journal

Vol 2, No 2, November 2019

provided loans, etc. After 1990, the two-level system was established. The Bank of Albania (BoA) or the Central Bank (CB), which represented the first level, was created by the Albanian State Bank. Commercial Banks, National Commercial Bank (NCB) and the Agrarian Trade Bank (ATB) were established, representing the second level. For the Central Bank, the primary objective, the political instruments in use, its functions, etc. were sanctioned by law. Loans for economic entities, businesses and citizens were only provided by Commercial Banks or Second Level Banks, which aimed at maximizing profit. We divide the mode of functioning of the political instruments of the BoA in three periods.

The first period is from 1990 to 1997 . By 1997, BoA applied direct monetary policy instruments such as the lower deposit interest rate, the upper limit of the interest rate on loans and the credit limit. State-owned banks, the National Commercial Bank, the Agrarian Trade Bank and the Insurance Agency operated. A few foreign-owned private banks have been operating.

Second period is from 1997 to 2003. In 1997, the crisis of money, the crisis of the monetary system broke out. After the crisis of burglaries bankrupt the Agrarian Trade Bank while the National Commercial Bank was privatized. The Savings Agency was converted into "Savings Bank". After this year, loans to businesses from state-owned banks go to zero. They gave little credit, only foreign banks, in foreign currency, mostly in the drachma, and the dollar. In the last months of 2003, the Savings Bank was also privatized. After 2000 foreign currencies were converted into euros. Start lending in euro and in lek. In this period of time, the loan in euro was higher than the loan in ALL. From 1997 to 2003, BoA applies direct monetary policy instruments and indirect instruments. Indirect instruments include open market operations, REPO rates, and mandatory reserve rate. In 1997, the central objective of the Central Bank (Law No.8269, CB 1997) was set "achieving and maintaining the level of prices".

The third period starts from 2004 to the present day. The Central Bank only applies indirect instruments. In circulation are three coins Albanian lek (All) euro and dollar. The $\mathrm{NBI}=\mathrm{REPO}=$ Repurchase Agreement is determined by the Bank of Albania, while the Euro Core Interest Rate is determined by the European Central Bank and the dollar is determined by the US FED. Until 2004, the currency was dominant in the credit market, while it had a smaller share in the deposit market. After 2004, especially after 2008, the BoA applied an expansionary monetary policy. The results of this policy will be analyzed in this paper. This period became the subject of study because, in our opinion, the BoA's monetary policies did not have any impact on the main economic indicators, on the contrary, in some of them they had negative impacts. From this analysis we have come to conclusions, how should we act in the future so that, in combination with fiscal policies, the BoA's monetary policies become effective. 


\section{Journal of International Cooperation and Development}

www.richtmann.org/journal

Vol 2, No 2, November 2019

\section{Influence of BoA's Monetary Policy on Inflation Rate}

The main objective of the BoA under the 1997 law is "achieving and maintaining the level of prices". One of the main indirect political instruments that it uses to achieve this objective is the Core Interest Rate or REPO. Its decline presupposes the release of money in circulation, and consequently, an increase in the inflation rate. The Central Bank has lowered this instrument from 2008 to 2018 from $6.25 \%$ to $1 \%$. This policy should lead to an increase in the inflation rate. This phenomenon has not happened.

The inflation rate, in the Albanian economy has not been high, it has not brought negative consequences to the economy. Only in 1997, when the pyramid firms went bankrupt, the inflation rate reached over $40 \%$. After this year and onward, it stabilized within the forecasted rate by the $\mathrm{CB}$ at $3 \%$ with fluctuations $+1 \%$ and $-1 \%$. Generally, it has been below the $3 \%$ level. The main reasons in our opinion are three, the low level of output, the imported inflation and the monetary mix market.

Even for 2019, according to INSTAT, it continues to be low, below the $2 \%$ level. In January it was $1.9 \%, 1.7 \%$ in February, $1.1 \%$ in March and $1.4 \%$ in April.

Taking into account the low inflation rate, the Bank of Albania, in our opinion, had no reason to apply an expansionist monetary policy. The implementation of this policy has brought more negative consequences and few positive consequences to the economy. The effect of monetary policy transmission, in achieving the core objective of the Central Bank, has been negligible. The Bank of Albania has little or no effect on controlling the inflation rate. The government's fiscal policies, tax policies, revenue policies and customs policies have a greater impact. The effect of the monetary policy transmission is shown in Table 1.

Table 1: Inflation rate dynamics and REPOs (2008-2018)

\begin{tabular}{|c|c|c|c|}
\hline & Inflation & REPO Repurchase agreement & Inflation forecast \\
\hline 2008 & 3.4 & 6.25 & 3 \\
\hline 2009 & 2.3 & 5.25 & 3 \\
\hline 2010 & 3.37 & 5 & 3 \\
\hline 2011 & 1.7 & 4.75 & 3 \\
\hline 2012 & 2.4 & 4 & 3 \\
\hline 2013 & 1.9 & 3 & 3 \\
\hline 2014 & 0.66 & 2.25 & 3 \\
\hline 2015 & 1.96 & 1.75 & 3 \\
\hline 2016 & 2.18 & 1.25 & 3 \\
\hline 2017 & 1.8 & 1.25 & 3 \\
\hline 2018 & 1.8 & 1 & 3 \\
\hline
\end{tabular}

Source: Bank of Albania 


\section{Journal of International Cooperation and Development \\ www.richtmann.org/journal \\ Vol 2, No 2, November 2019}

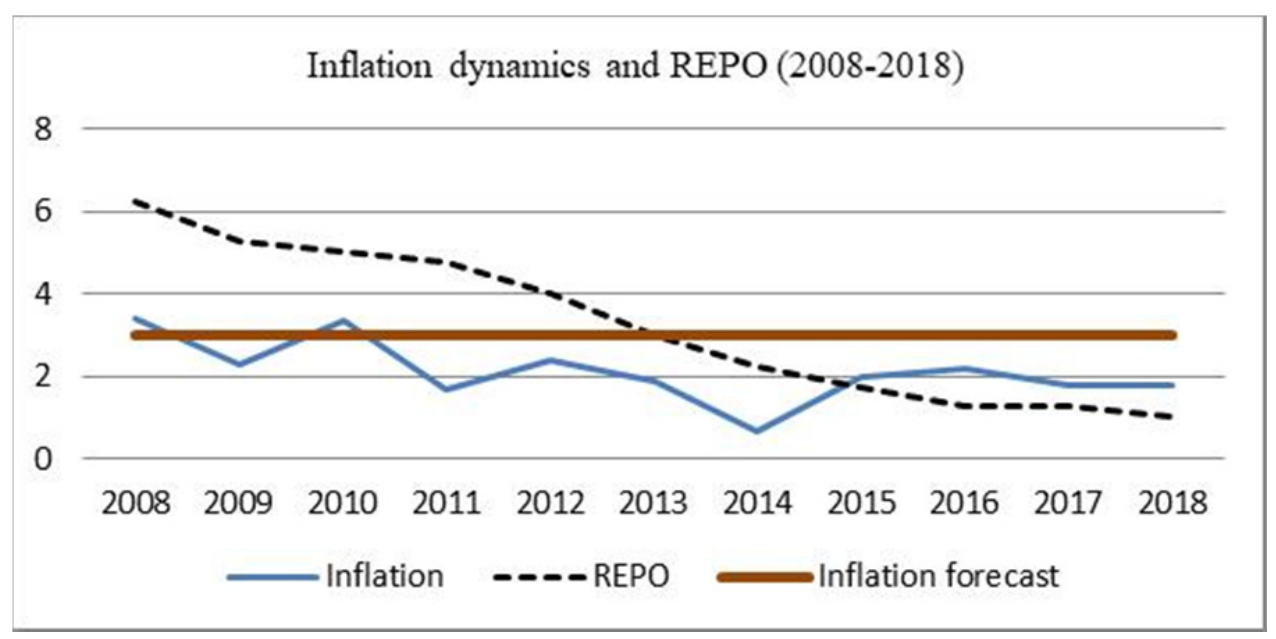

Fig. 1: Inflation rate dynamics and REPOs (2008-2018)

Source: Authors

The data show that inflation is closer to the lower limit of $2 \%$. From 2010 onwards, it has never been in the quota provided by the BoA, $3 \%$. The upper limit has only been passed in cases of financial crises such as 1997 and 1998 , respectively $42 \%$ to $8.7 \%$.

The correlation coefficient between the inflation rate and the REPOs for the years 2008-2018 was 0.6214. This coefficient shows that the link between the two indicators is very low, and with a positive sign. The normal connection would be the opposite; it would be a negative sign. The decline in the rate of REPOs had to be accompanied by the growth of All's volume in circulation, to the extent that would increase inflation rate. This effect did not happen, but the opposite was true, the inflation rate did not follow the dynamics of the REPOs.

\section{Linking Monetary Policies to the Growth of the Economy. The Albanian Economy is in the Liquidity Trap}

What does it mean, Liquidity Trap? Liquidity trap means; failure of the Central Bank's monetary policy transmission effect, or failure of its monetary policy effect. The Central Bank, considering the monetary situation in the country, the state of the monetary aggregates, the magnitude and dynamics of the main macroeconomic indicators, compiles and implements its policies with the aim of achieving the relevant objectives for short and long term periods and to influence them in improving other indicators.

In a normal country this Central Bank policy transmission effect would function:

Central Bank $\rightarrow \downarrow$ REPO $\rightarrow \downarrow$ Deposit All $\rightarrow \downarrow$ Credit All $\rightarrow \uparrow$ Loan Structure $\rightarrow \uparrow$ Investment $\rightarrow$ Production $\uparrow($ Naqellari A 2018). 
There is a different connection in Albania.

Central Bank $\rightarrow \downarrow$ REPO $\rightarrow \downarrow$ Deposits $\rightarrow \downarrow$ Deposit Story All $\rightarrow \downarrow$ Credit All $\rightarrow \uparrow$ Loan Structure $\rightarrow \uparrow$ Investment (very low levels in 2018 decreased compared to 2017) $\rightarrow \uparrow$ Production.

Generally, production growth has come from foreign investment.

Economic growth had to be accompanied by increased savings, in fact the opposite was true.

Economic growth is not accompanied by increased deposits.

This indicates that there is no increase in the indicators that directly affect the development of the economy, but there is an increase in indicators that are simply reflected in GDP growth.

Under these conditions, Hick-Hansen's IS-LM model cannot be applied.

Models of Hick-Hansen

(A)

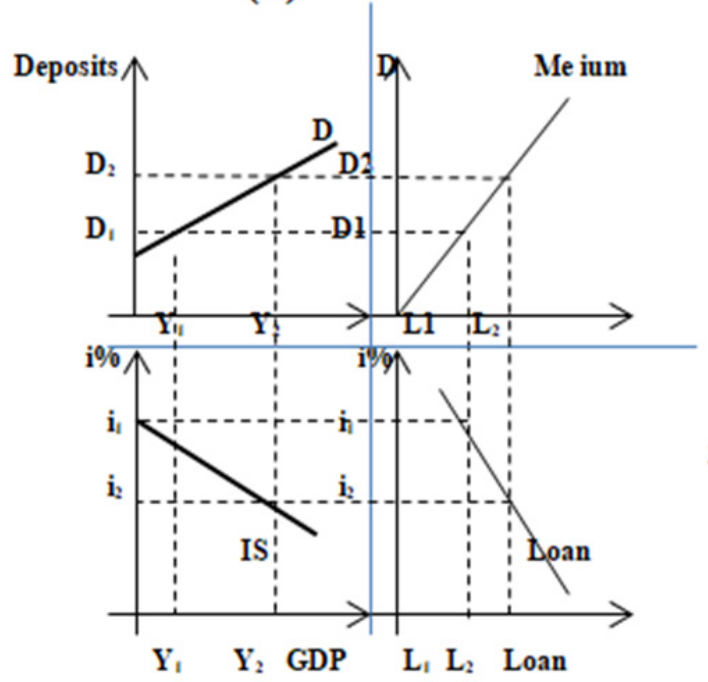

The relationship between deposit and GDP (2013-2018

(B)

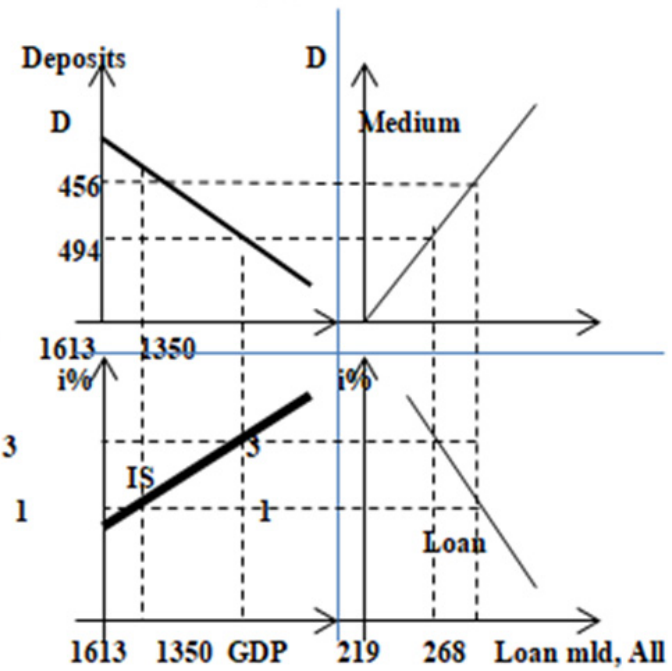

Fig. 2: The Theoretical Model Hick-Hansen and the Data Model from the Albanian Economy

Models (A). In the Hicks-Hansen model (Santillana A, Sanchez A 2012-2013) (Angela A, Kadriu A, Naqellari A, 2010) the relationship between GDP and Deposit is positive. That is to say, the more GDP growth, the more deposits will grow. The GDP curve relative to the interest rate is negative. This shows that the lower the interest rates, the more GDP growth.

Models (B). This model is built with the original data obtained from the Central Bank Statistical Reports. GDP of 2018 is calculated from 2017 GDP (plus 4\% increase in 


\section{Journal of International Cooperation and Development}

www.richtmann.org/journal

Vol 2, No 2, November 2019

2018). The normal theoretical model cannot be built because economic growth is not associated with increased savings. The built-in model is absurd. This model proves that Central Bank policies have had no impact on the growth of the economy, on the contrary, as a result of the decline in deposits, had a negative impact. If the savings were unchanged then the IS curve would be completely inelastic. This would indicate that there was no economic growth in Albania under these conditions. The further reduction of the REPO rates will have no effect on the growth of deposits and loans because it is moving to zero ( 0.75 deposit interest rate while the real rate is negative).

\section{Impact of Monetary Policy on the Dynamics and Structure of Deposits}

The dynamics of savings deposits in lek and in foreign currency is reflected in Table No.2.

Table 2: The dynamics of deposits and loans in All(lek)

\begin{tabular}{|c|c|c|c|c|c|c|c|c|c|}
\hline & \multicolumn{2}{|c|}{ Deposits } & mld/All & & & & GDPr \\
\cline { 2 - 11 } & Total (All+ currency) & \% of growth & All & $\begin{array}{c}\text { \% of } \\
\text { growth }\end{array}$ & \% to total & Time & $\begin{array}{c}\text { \% of } \\
\text { growth }\end{array}$ & \% to total & $\begin{array}{c}\text { \% of } \\
\text { growth }\end{array}$ \\
\hline 2008 & $614,824.90$ & 100 & $354,125.00$ & 100 & 57.6 & $262,261.00$ & 100 & 74.1 & 7.5 \\
\hline 2009 & $662,425.70$ & 7.7 & $369,137.70$ & 4.2 & 55.7 & $293,675.90$ & 11.9 & 79.6 & 3.3 \\
\hline 2010 & $785,225.00$ & 18.5 & $409,458.40$ & 10.9 & 52.1 & $329,090.00$ & 12.0 & 80.4 & 3.7 \\
\hline 2011 & $875,226.30$ & 11.5 & $452,080.10$ & 10.4 & 51.7 & $370,105.20$ & 12.4 & 81.9 & 2.5 \\
\hline 2012 & $930,702.80$ & 6.3 & $476,872.00$ & 5.4 & 51.2 & $388,330.50$ & 4.9 & 81.4 & 1.4 \\
\hline 2013 & $950,088.30$ & 2.1 & $494,279.50$ & 3.6 & 52.0 & $397,295.60$ & 2.3 & 80.4 & 1.0 \\
\hline 2014 & $977,420.70$ & 2.9 & $504,691.10$ & 2.1 & 51.6 & $369,035.00$ & -7.1 & 73.1 & 1.8 \\
\hline 2015 & $985,573.90$ & 0.8 & $492,352.70$ & -2.4 & 50.0 & $338,847.20$ & -8.1 & 68.8 & 2.2 \\
\hline 2016 & $1,014,197.30$ & 2.9 & $487,687.60$ & -0.9 & 48.1 & $301,511.70$ & -11.0 & 61.8 & 3.4 \\
\hline 2017 & $1,001,670.70$ & -1.2 & $473,663.80$ & -2.8 & 47.3 & $277,349.90$ & -8.0 & 58.6 & 3.9 \\
\hline 2018 & $988,824.10$ & -1.3 & $456,198.80$ & -3.6 & 46.1 & $252,762.50$ & -8.8 & 55.4 & 4 \\
\hline
\end{tabular}

Source: Bank of Albania

\begin{tabular}{|c|c|c|c|c|c|c|}
\hline & Currency & \% of growth & $\%$ & Time & \% of growth & $\%$ \\
\hline 2008 & $260,699.90$ & 100 & 42.4 & $195,586.20$ & 100 & 75.0 \\
\hline 2009 & $293,288.00$ & 12.5 & 44.3 & $217,865.30$ & 11.4 & 74.3 \\
\hline 2010 & $375,766.60$ & 28.1 & 47.9 & $288,294.80$ & 32.3 & 76.7 \\
\hline 2011 & $423,146.20$ & 12.6 & 48.3 & $336,393.20$ & 16.7 & 79.5 \\
\hline 2012 & $453,830.80$ & 7.25 & 49 & $364,624.20$ & 8.4 & 80.3 \\
\hline 2013 & $455,808.80$ & 0.44 & 48 & $346,181.20$ & -5.1 & 75.9 \\
\hline 2014 & $472,729.60$ & 3.71 & 48 & $324,872.70$ & -6.1 & 68.7 \\
\hline 2015 & $493,221.20$ & 4.33 & 50 & $299,302.90$ & -7.9 & 60.7 \\
\hline 2016 & $526,509.70$ & 6.75 & 52 & $276,389.20$ & -7.7 & 52.5 \\
\hline 2017 & $528,006.90$ & 0.28 & 53 & $260,593.80$ & -5.7 & 49.4 \\
\hline 2018 & $532,625.30$ & 0.87 & 54 & $243,392.60$ & -6.6 & 45.7 \\
\hline
\end{tabular}

Source: Bank of Albania 


\section{Journal of International Cooperation and Development \\ www.richtmann.org/journal \\ Vol 2, No 2, November 2019}

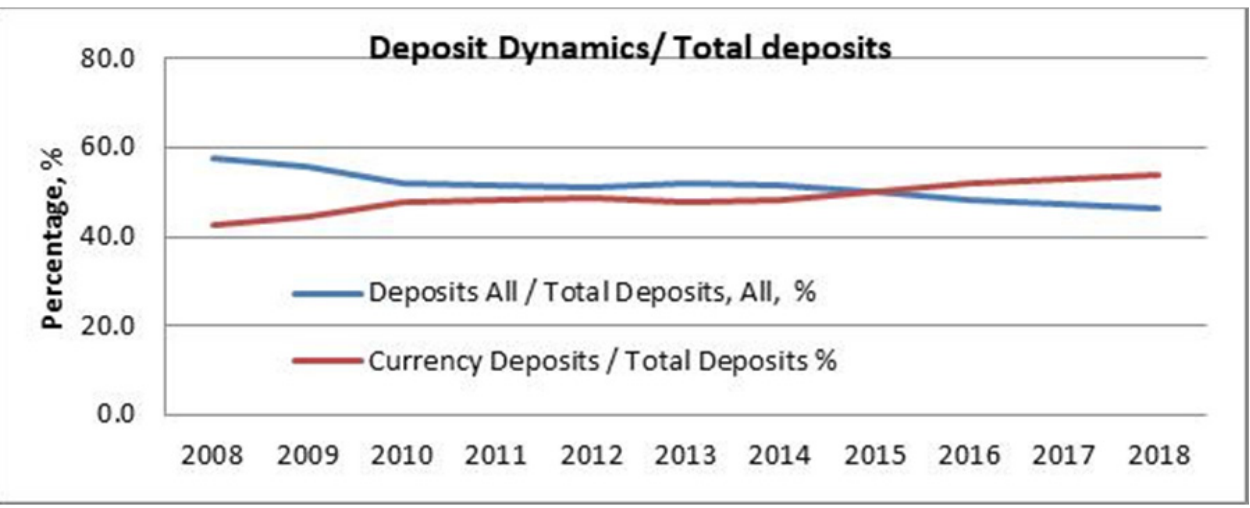

Fig. 3: Dynamics of deposits to total deposits in All and foreign currency Source: Authors

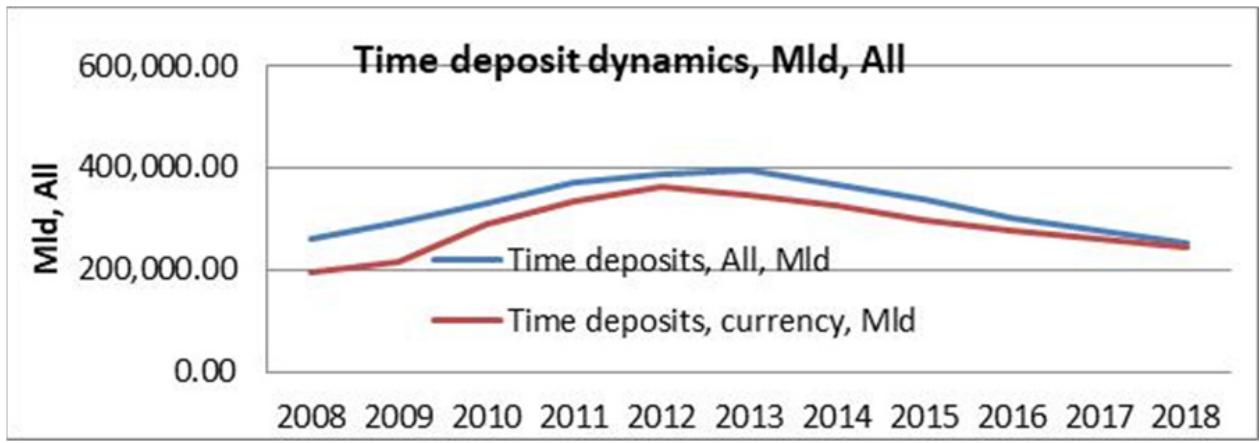

Fig. 4: The dynamics of time deposits in All and foreign currency

Source: Authors

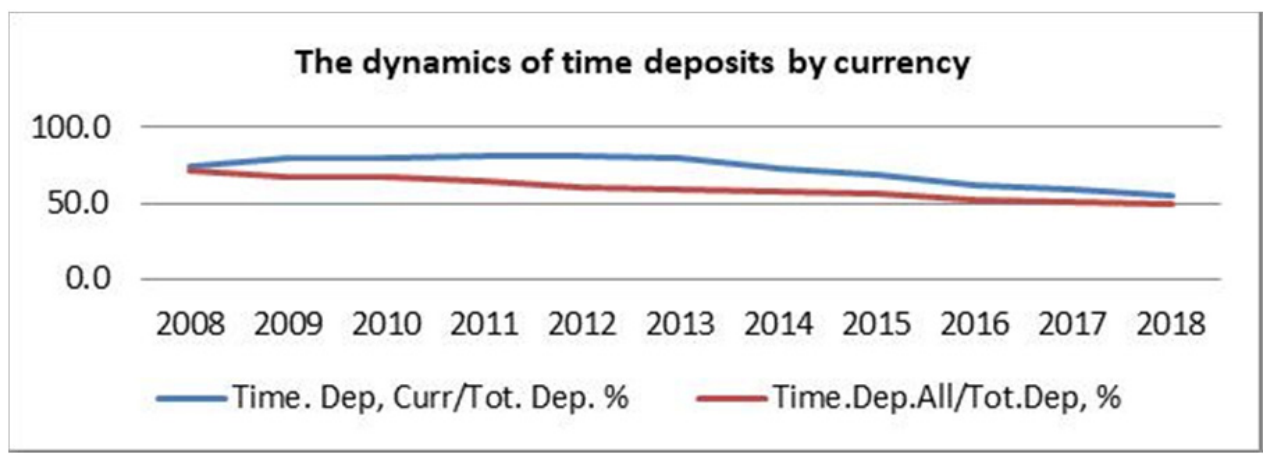

Fig. 5: The dynamics of time deposits in All and currency in\% to total Source: Authors 


\section{Journal of International Cooperation and Development}

www.richtmann.org/journal

Vol 2, No 2, November 2019

From the data analysis of Table No.2 and Figures no. 3, 4 and 5 we draw the following conclusions:

2008 is the year with the highest growth rate of $7.5 \%$. It is the year when the consequences of the financial crisis and global recession emerged. By 2013 the growth rate has decreased, in 2013 it was 1\%. From 2014 to 2018, it has been increased every year. This dynamics of economic growth was not accompanied by the total deposit dynamics in percentage.

Deposit dynamics. The economic downturn has been accompanied by the fall in total deposit growth rates. By 2010, total deposits by 2018 have increased and decreased. In 2010 they increased by 18.5\%, in 2018 compared with 2017, down by $1.2 \%$. In absolute terms, the total All + currency deposits have increased. In the years 2017 and 2018 have decreased. The same situation is for total deposits in lek. Their downfall is greater. Every year, from 2015 to 2018, they have fallen. Even in absolute terms, total lek deposits have decreased from 2013 to 2018. Time deposits in All from 2015 to 2018 have decreased. Even in absolute terms from 2013 to 2018 have decreased.

The growth rate of total foreign currency deposits has fallen sharply, from $28.1 \%$ in 2010 to 2018 , down to $0.87 \%$. This trend is also seen in foreign currency time deposits, which from 2012 to 2018 are minus signs. In absolute terms, total foreign currency deposits have increased, while time deposits in foreign currency have decreased.

The overall conclusion is that there is no positive relation between growth and deposit growth. Time deposits in ALL and in foreign currency in absolute terms from 2013 to 2018 have decreased. The correlation coefficient for these two indicators, from 2013 is -0.987 (economic growth, time deposits in lek) and -0.985 (economic growth, time deposits in foreign currency). In the normal economy, the opposite should happen.

Interest rate dynamics. Deposit depreciation has also come as a result of falling real interest rates. For the years 2015, 2016, 2017 and 2018 real interest rates have been negative. This means that depositors have lost hundreds of millions of ALL purchasing power. They are lost because the interest rate on deposits is not indexed by commercial banks in relation to the inflation rate. This loss of depositors has had an impact on the growth of commercial bank profits. In the analysis that the Central Bank of Albania does not emphasize this important fact, the loss of Albanian depositors, but the bank's profit is seen as a positive indicator of the stability of the financial system.

Interest is also the analysis of deposit interest rate dynamics, relative to the rate of REPOs and economic growth. The correlation coefficient between 12-month ALL deposits with the REPO rate from 2013 to 2018 was 0.96, while in relation to 2008 it was approximately 0.99. Very strong link. Conclusion: the decrease of the rate of REPOs is reflected in the reduction of the deposit rate in lek. The decline of the deposit rate has affected the reduction of their stock, in absolute terms and in percentage. 


\section{Journal of International Cooperation and Development}

www.richtmann.org/journal

Vol 2, No 2, November 2019

Table 3: Some macroeconomic indicators in percentage

\begin{tabular}{|c|c|c|c|c|c|}
\hline & GDPr in \% & REPO in \% & $\begin{array}{c}\text { Interest rate on } \\
\text { deposits \% }\end{array}$ & $\begin{array}{c}\text { Interest rate } \\
\text { on loans \% }\end{array}$ & $\begin{array}{c}\text { Deposit rate - the } \\
\text { inflation rate }\end{array}$ \\
\hline 2008 & 7.5 & 6.25 & 6.86 & 11.11 & 3.46 \\
\hline 2009 & 3.35 & 5.25 & 6.75 & 12.04 & 4.45 \\
\hline 2010 & 3.71 & 5 & 6.4 & 11.29 & 3.03 \\
\hline 2011 & 2.55 & 4.75 & 5.87 & 11.17 & 4.17 \\
\hline 2012 & 1.40 & 4 & 5.38 & 10.28 & 2.98 \\
\hline 2013 & 1.00 & 3 & 4.17 & 9.52 & 2.27 \\
\hline 2014 & 1.80 & 2.25 & 1.92 & 7.66 & 1.26 \\
\hline 2015 & 2.20 & 1.75 & 1.35 & 7.79 & -0.61 \\
\hline 2016 & 3.40 & 1.25 & 0.8 & 5.89 & -1.38 \\
\hline 2017 & 3.95 & 1.25 & 0.75 & 5.98 & -1.05 \\
\hline 2018 & 4 & 1 & 0.73 & 5.65 & -1.07 \\
\hline Correlation & with GDP & -0.962 & -0.882 & -0.968 & \\
\hline
\end{tabular}

Source: Bank of Albania

Strong correlations with economic growth have credit rates of -0.968 , deposit interest rates are almost strong with -0.88 .

Deposit structure. In 2008, ALL deposits accounted for $57.6 \%$ of the total, while deposits in the currency accounted for $42.4 \%$. In 2015 they were almost equalized. In the following years, deposits in foreign currency totaled more than ALL deposits. Thus in 2018 ALL deposits accounted for $46 \%$ of the total while those in foreign currency accounted for $54 \%$. Even time deposits have had the same dynamics. Deposits in foreign currency have increased and ALL deposits decreased. In 2018, time deposits in lek and foreign currency were almost equalized. This is clearly seen in figure no. 4. The change in the structure of deposits has also influenced the interest rates of euro deposits and deposits in lek. Initially the difference was great, but over the years it was reduced, because the deposit rate in lek decreased to $0.75 \%$. In this way the euro has been a strong competitive currency that has influenced the deposit and credit stock. The Euro's core interest rate is set by the European Central Bank, while All is set by the Bank of Albania. Since 2008, the CIR of the euro has been very low in relation to the lek rate of 6.25 , so the lek was in disadvantage with the euro both in deposits and in loans. In 2008, lek deposits accounted for most of the market. In 2015, the total deposits in foreign currency were equalized and in 2018 the time deposits were equalized. At present, the deposit market is almost 50\% All / 50\% currency. 


\section{The Impact of Monetary Policies on the Dynamics and Structure of Loans}

In the growth of the economy are influenced by the two main factors, Work (L) and Capital (K). In Albania, little can be said about the impact of productivity. In the capital group are influenced the investments of firms themselves, bank loans, foreign investments etc. In this analysis, we have exposed two indicators, investments in the spending group and the stock of bank loans. As far as the Labor factor is concerned, its impact has been negative, because every year thousands of workers have left Albania.

The Gross Fixed Capital Formation (GDP) in the calculation of GDP has been decreasing and increasing. In 2010, 2012, 2013, 2014 there were negative signs. In 2015, 2016, 2017 and 2018 there were respectively $3.88 \%, 2.47 \%, 6.06 \%$ and $3 \%$ respectively. The correlation coefficient for the years 2008-2018 between GFCF and GDP in\% was 0.374 , for the years $2013-2018$ it was 0.682 . This connection is weak. In this way we can say that these main indicators of GDP growth have given very low and often negative impact on the growth of the economy. This conclusion is also true of the banking system loans.

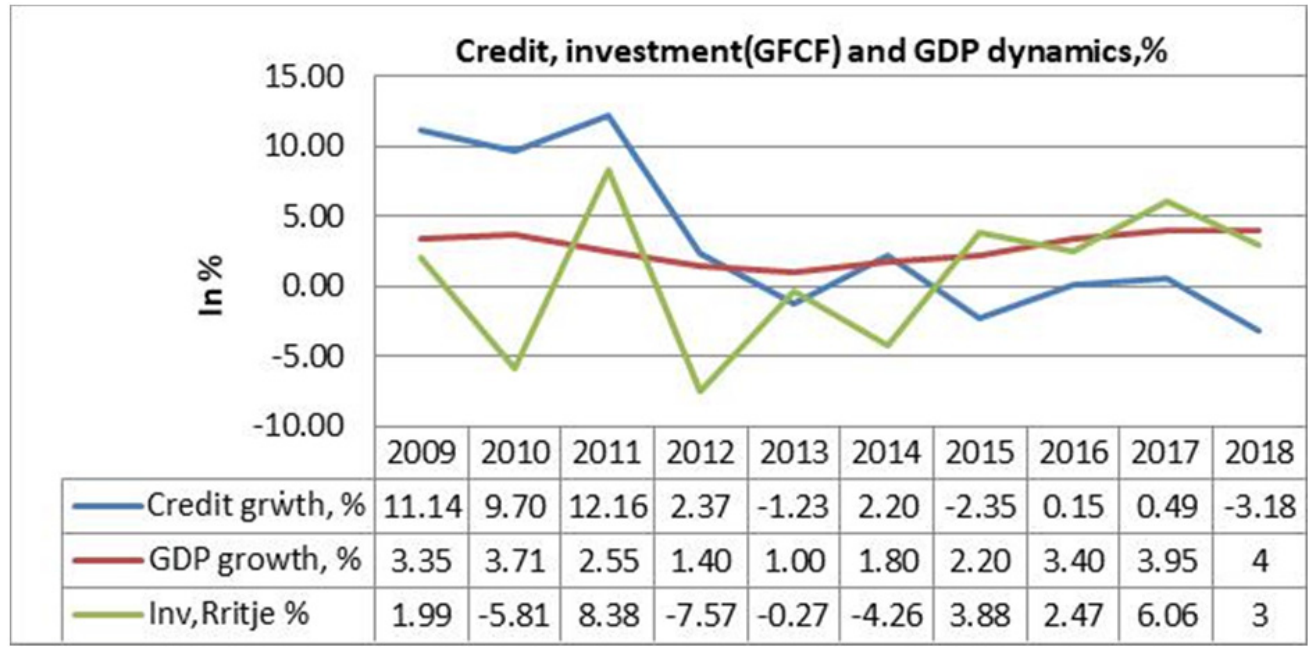

Fig. 6: The dynamics of loans, investments (GFCF) and GDP in percent

Source: Bank of Albania. Processing by authors

One of the main factors influencing the growth of the economy is credit growth. The Bank of Albania, through monetary policy, seeks to achieve its main and non-core objectives and for this use indirect instruments. Generally, it uses the rate of REPOs, which aims to reduce the interest rate on deposits and consequently reduce the interest rates on ALL loans. 


\section{Journal of International Cooperation and Development \\ www.richtmann.org/journal \\ Vol 2, No 2, November 2019}

On the other hand, Commercial Banks, with private capital, and many foreign ones, have no purpose to achieve the objectives of the Central Bank but aim at maximizing profit. Thus, the Central Bank actions they use in their interest. It does not matter whether the Central Bank realizes or does not achieve its objectives. This change of interest is reflected in the money market, on the level of loans, loans, deposits, debt instruments, and so on.

Commercial banks have reacted consistently; they have significantly reduced the deposit interest rate, while the credit rates have not decreased at the same rate. They have acted in their interest, in the interest of increasing profits.

Credit to the economy in Albania is low in nominal GDP. Nonetheless, it has an impact on GDP growth.

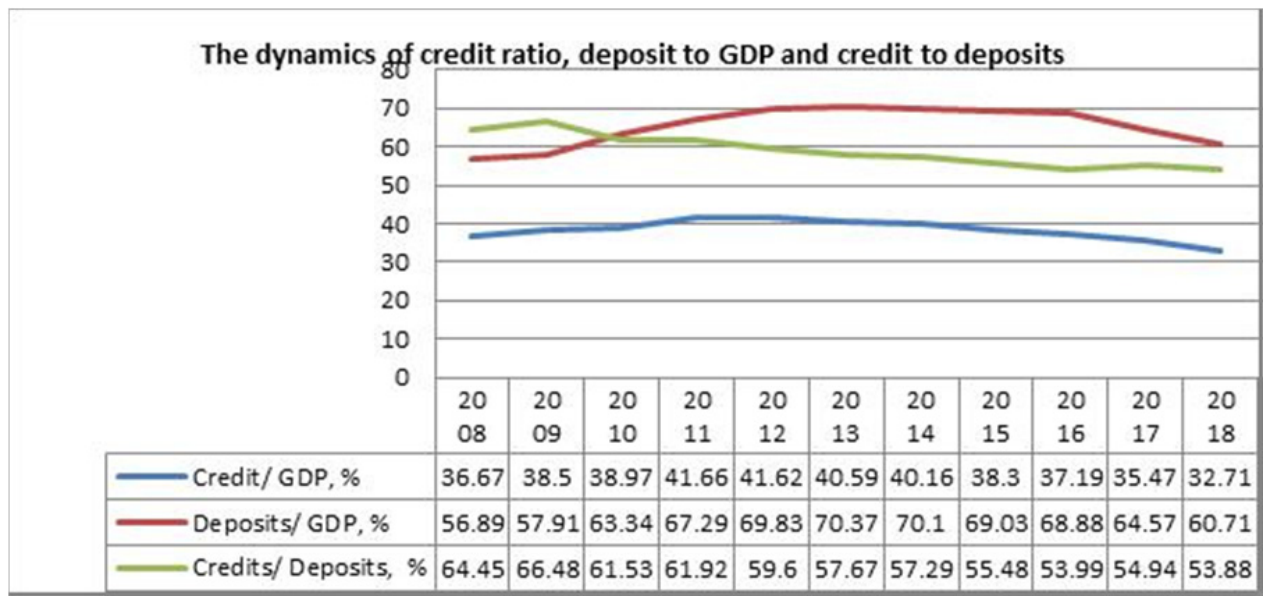

Fig. 7: Credit dynamics ratio, deposit to GDP and credit to deposits

Source: Bank of Albania

The ratio between loans and deposits has decreased since 2013. In 2013, loans accounted for $57.7 \%$ of deposits, while in 2018 they accounted for $53.9 \%$. This is an indicator of a negative impact on the growth of the economy. This shows that a large part of deposits are directed to other products that do not directly affect the growth of the economy.

Credit to GDP ratio is quite low. In 2013 it was $40.6 \%$ and in 2018 it was $32.7 \%$. It is also lower than other countries in the region. Its impact on GDP growth has been small.

The ratio between deposit and GDP is low. In 2013, deposits accounted for $70.4 \%$ of GDP, while in 2018 they accounted for $60.7 \%$. The decline in deposits has also negatively affected the decline in loans.

Credit to the economy from 2008 to 2012 has increased. Real GDP for these years has decreased. This shows that their relationship has been negative. In the following 


\section{Journal of International Cooperation and Development}

www.richtmann.org/journal

Vol 2, No 2, November 2019

period there was no sustainability, in 2013 decreased, in 2014 increased, in 2015 and 2016 decreased, in 2017 increased and in 2018 decreased. The general trend in these years is the downturn. From 2013 to 2018, according to INSTAT, real GDP has increased. In this way, there is no connection between the economic growth and the growth of loans from commercial banks. The correlation coefficient for these two indicators for 2008-2012 was 0.755, while for 2013-2018 it was -0.166. These data show that the level of loans has not been in harmony with the dynamics of GDP both in absolute terms and in percentage. The conclusion is simple; the banking system has not had any impact on the growth of the Albanian economy, on the contrary in a few years $(2013,2015,2016$, 2018) has had a negative impact.

What were some of the reasons that there is no consistent, unrelated relationship between GDP dynamics and credit dynamics for the economy, and credit in general?

Firstly, there are bad loans that have been rising despite their extraordinary spread. One of the consequences of these bad loans has been the melting and absorption of four commercial banks. Today, the Banking System does not operate 16 banks but 12 banks. At this low level of lending, they have affected, the difficult conditions to take credit, set by the Commercial Banks, are their high interest, and so on. These remove creditors from the banks, and turn to informal roads.

What has been the Central Bank's response to credit reduction? "They are not just the main banks' lending problem. We have to understand that banks are one side; the other side is the economy, the market, and the projects. Banks finance projects that meet the funding criteria. The more good projects are, the more banks will respond to these projects "(BoA 2019).

Secondly, the structure of loans by currency, credit until 1996 was generally in Lek, and was provided by state-owned banks.

After 1997, the credit focused on foreign currency, which was mainly issued by foreign-owned private banks.

After 2003, banks used three coins, which had different Base Rate of Interest (NBI). $\mathrm{NBI}$ and All was determined by the BoA, the NBI of the euro was determined by the European Central Bank and the NBI of the dollar was determined by the Fed.

In 2008 ALL loans accounted for $28.8 \%$ of total loans, while foreign currency loans accounted for $71.2 \%$. Gradually Lek denominated loans grew, in 2018 it accounted for $50.5 \%$ of the total, while in foreign currency it was $49.5 \%$. In this way, the monetary market is almost completely balanced, with a ratio of $50 \%$ to $50 \%$ in ALL loans with foreign currency loans. Absolute credits have been raised in lek despite the decrease of ALL deposits. The opposite has been with the trend of foreign currency loans and deposits. The loan has fallen, while rising deposits. 


\section{Journal of International Cooperation and Development}

www.richtmann.org/journal

Vol 2, No 2, November 2019

Table 4: Structure and dynamics of deposits

\begin{tabular}{|c|c|c|c|c|c|c|c|c|c|}
\hline & Loan & \multicolumn{2}{|c|}{ Mld/All } & \multicolumn{3}{c|}{ Mld/All } & \\
\cline { 2 - 11 } & Total & & $\%$ & All & & $\%$ & Currency & & $\%$ \\
\hline 2008 & $396,264.3$ & & 100 & $114,051.9$ & & 28.8 & $282,212.4$ & & 71.2 \\
\hline 2009 & $440,397.4$ & 11.14 & 100 & $140,479.9$ & 23.17 & 31.9 & $299,917.5$ & 6.27 & 68.1 \\
\hline 2010 & $483,129.70$ & 9.70 & 100 & $157,197.30$ & 11.90 & 32.5 & $325,932.40$ & 8.67 & 67.5 \\
\hline 2011 & $541,899.80$ & 12.16 & 100 & $188,779.10$ & 20.09 & 34.8 & $353,120.70$ & 8.34 & 65.2 \\
\hline 2012 & $554,732.20$ & 2.37 & 100 & $215,122.70$ & 13.95 & 38.8 & $339,609.50$ & -3.83 & 61.2 \\
\hline 2013 & $547,927.50$ & -1.23 & 100 & $219,933.00$ & 2.24 & 40.1 & $327,994.50$ & -3.42 & 59.9 \\
\hline 2014 & $559,986.90$ & 2.20 & 100 & $233,443.00$ & 6.14 & 41.7 & $326,543.90$ & -0.44 & 58.3 \\
\hline 2015 & $546,803.90$ & -2.35 & 100 & $240,793.90$ & 3.15 & 44.0 & $306,010.00$ & -6.29 & 56.0 \\
\hline 2016 & $547,602.50$ & 0.15 & 100 & $259,547.60$ & 7.79 & 47.4 & $288,054.90$ & -5.87 & 52.6 \\
\hline 2017 & $550,280.50$ & 0.49 & 100 & $273,261.90$ & 5.28 & 49.7 & $277,018.60$ & -3.83 & 50.3 \\
\hline 2018 & $532,800.00$ & -3.18 & 100 & $268,872.20$ & -1.61 & 50.5 & $263,949.10$ & -4.72 & 49.5 \\
\hline
\end{tabular}

Source: Bank of Albania

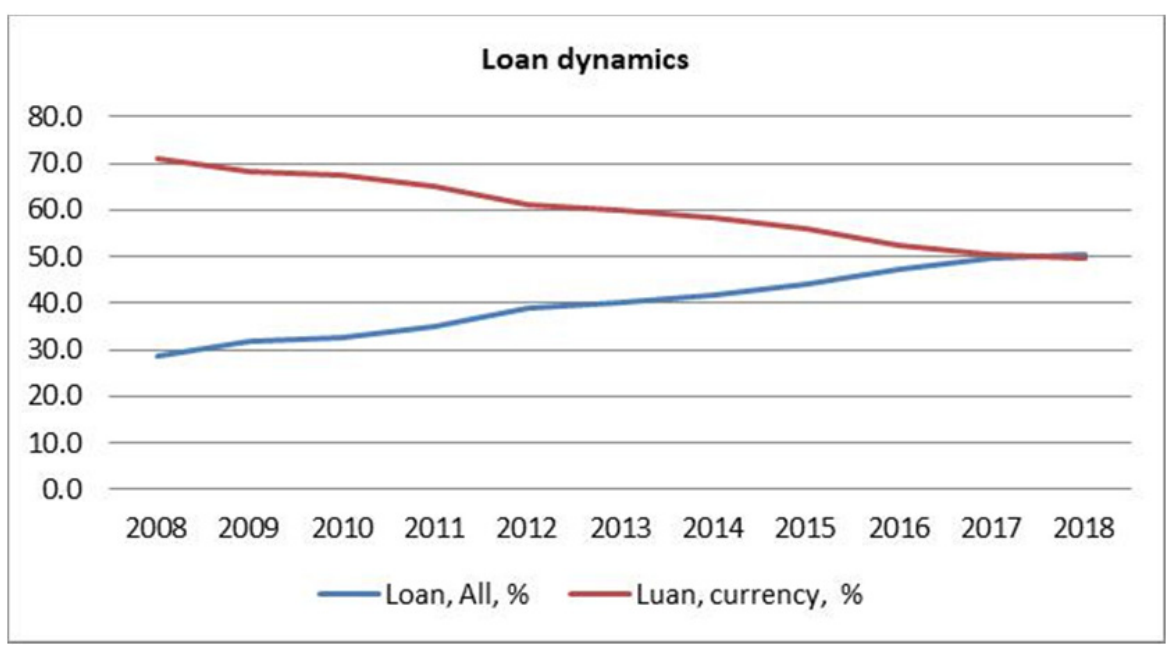

Fig. 8: Loan dynamics in lek and foreign currency

Sources: Authors

Thirdly the rate of interest rates, the Bank of Albania had higher interest rates than the European Central Bank and the Fed. As a result, foreign commercial banks maintained high interest rates on ALL loans. With these reports the Albanian Lek could not compete in the money market with the euro and the dollar. The problem of Lek spending in the country, the commercial banks had to settle because Lek was used for the purchase of Treasury Bills and Government Bonds. Interest rates on ALL loans were set high because Lek had a safe use destination. In this way, citizens and businesses sought loans in euros because they had interest rates much lower than the Lek. Commercial banks use the euro for loans, some of them are deposited outside Albania. The euro and the dollar are 
international money, so they can easily be used to loan foreign business and deposit them with interest.

Table 5: Dynamics of loans, and some other indicators

\begin{tabular}{|c|c|c|c|c|c|c|}
\hline & $\begin{array}{c}\text { Credit for } \\
\text { economy mld } \\
\text { /All }\end{array}$ & $\begin{array}{c}\text { Credit } \\
\text { Dynamics,\% }\end{array}$ & $\begin{array}{c}12 \mathrm{~m} \\
\text { interest } \\
\text { rates (\%) }\end{array}$ & $\begin{array}{c}\text { Weekly } \\
\text { repurchase } \\
\text { agreement rate }\end{array}$ & $\begin{array}{c}\text { Elasticity } \\
\text { coefficient. } \\
\text { interest rate-loans }\end{array}$ & $\begin{array}{c}\text { Elasticity } \\
\text { coefficient } \\
\text { REPO-loans }\end{array}$ \\
\hline 2008 & 396.3 & $\mathrm{x}$ & 11.75 & 6.25 & $\mathrm{x}$ & $\mathrm{x}$ \\
\hline 2009 & 440.4 & 11.13 & 12.46 & 5.25 & -0.70 & 1.84 \\
\hline 2010 & 483.1 & 9.70 & 11.29 & 5 & -2.04 & -1.03 \\
\hline 2011 & 541.9 & 12.17 & 11.17 & 4.75 & -2.43 & -11.45 \\
\hline 2012 & 554.7 & 2.36 & 10.28 & 4 & -0.15 & -0.30 \\
\hline 2013 & 547.9 & -1.23 & 9.52 & 3 & 0.05 & 0.17 \\
\hline 2014 & 560 & 2.21 & 7.66 & 2.25 & -0.09 & -0.11 \\
\hline 2015 & 546.8 & -2.36 & 7.77 & 1.75 & 0.11 & -1.64 \\
\hline 2016 & 547.2 & 0.07 & 5.89 & 1.25 & 0.00 & 0.00 \\
\hline 2017 & 550.3 & 0.57 & 5.98 & 1.25 & $\mathrm{x}$ & 0.37 \\
\hline 2018 & 532.8 & -3.18 & 5.65 & 1 & 0.16 & 0.58 \\
\hline
\end{tabular}

Source: Bank of Albania. Processing by authors

12-month Lek interest rates in Lek have dropped. From 11.75\% in 2008, in 2013 they were $9.52 \%$ and in 2018 they were $5.65 \%$. They have accompanied the dynamics of the REPO rate.

The correlation coefficient between the interest rates of REPOs and the interest rate of ALL loans for the years 2008-2018 has been 0.968 .

The correlation coefficient between loans and their interest rate was -0.65 . This indicates that the connection is normal, but its strength is low, without any noticeable effect. This link from 2013 to 2018 was 0.395 . The bond is positive, which means that the interest rates did not have a positive impact on the growth of the loan stock but had a negative impact. Their reduction has affected the reduction of the loan stock.

This trend is also seen in the analysis of elasticity coefficients. Elasticity coefficients from 2012 are very low. They express the links between interest rates on loans, REPOs and loans. In the last 3-4 years the Elasticity coefficient has been positive. This will mean that the link has been the same. The increase in interest rates has led to credit growth. These are indicators complementing the conclusions of the magnitude of correlation coefficients. In this way we can say that interest rates, since 2013, have not had any impact on the growth of the stock of loans.

Fourth, maintaining and increasing the level of profit from commercial banks. Interesting is the comparison of interest rates on loans with interest rates on deposits. 


\section{Journal of International Cooperation and Development \\ www.richtmann.org/journal \\ Vol 2, No 2, November 2019}

This is presented in the table no. 6.

Table 6: Interest rates on deposits and loans

\begin{tabular}{|c|c|c|c|}
\hline & Interest rate (12m) of deposits in All & Interest rate (12) of loans in All & Difference \\
\hline 2008 & 6.86 & 11.11 & 4.25 \\
\hline 2009 & 6.75 & 12.04 & 5.29 \\
\hline 2010 & 6.4 & 11.29 & 4.89 \\
\hline 2011 & 5.87 & 11.17 & 5.3 \\
\hline 2012 & 5.38 & 10.28 & 4.9 \\
\hline 2013 & 4.17 & 9.52 & 5.35 \\
\hline 2014 & 1.92 & 7.66 & 5.74 \\
\hline 2015 & 1.35 & 7.79 & 6.44 \\
\hline 2016 & 0.8 & 5.89 & 5.09 \\
\hline 2017 & 0.75 & 5.98 & 5.23 \\
\hline 2018 & 0.73 & 5.65 & 4.92 \\
\hline
\end{tabular}

Source: Bank of Albania

Chart and chart data show that the difference between interest rates on loans and deposits in All is very large. They are sitting very little. REPO rates from 2008 to 2018 decreased from 6.25 to 1 . Deposit rates decreased from 6.86 to 0.73 or 9.3 times. The interest rates on loans decreased from $11.11 \%$ in 2008 to $5.65 \%$ in 2018 , or by $50.8 \%$. Or it has been cut back 2 times.

The bond strength (deposit rates and credit rates) with REPO is high at 0.959 and 0.967 . The bond ratio between them (the deposit rate-credit rate) is very strong at 0.979 . These correlation indicators show that through these actions the Commercial Banks have reflected in their interest

These correlation indicators show that through these actions Commercial Banks have reflected in their interest the reduction of the rate of REPOs. They have maintained almost unchanged the difference between interest rates on deposits and loans. This has made their profits kept unchanged, while credit rates exacerbate creditors. Likewise, the inflation rate weighs on creditors because the real interest rate turns negative. Today (2019) in Albania the real deposit interest rate continues to be negative. This means that Albanian depositors do not win but lose in their purchasing power. 


\section{Journal of International Cooperation and Development}

www.richtmann.org/journal

Vol 2, No 2, November 2019

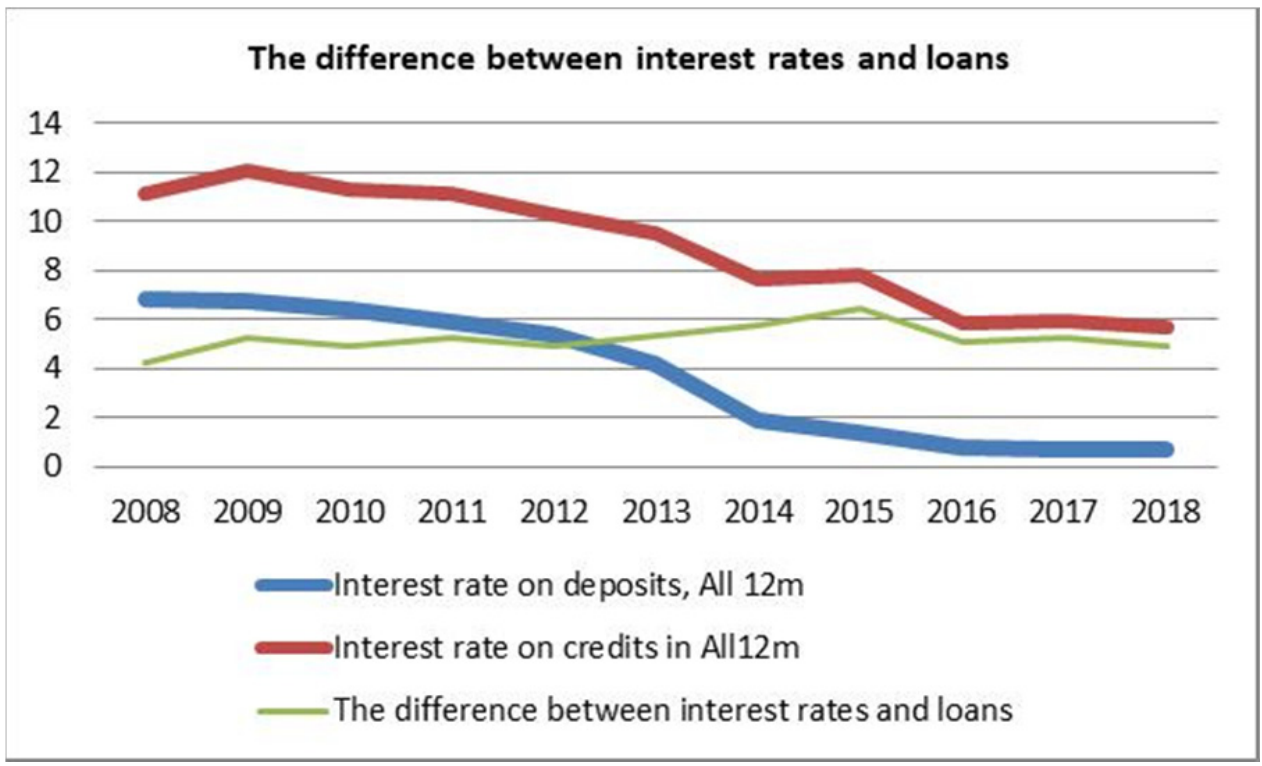

Fig. 9: Curve reflecting the difference between interest rates on loans and deposits Source: Authors

The dynamics of the difference between interest rates is very interesting. This difference since 2015 and onwards tends to the Interest Rate of Credit. This action seriously undermines the interest of Albanian depositors. Deposit interest rates are not indexed to the inflation rate. Precisely at this point, the Bank of Albania and the Competition Authority had to intervene, as it has to do with an aggravating effect on the consumer. This position of interest has the consequence of a large reduction of Lek deposits, thus damaging the Albanian economy.

Fifthly, credit structures by use, total loans by sectors of economy (Table No.5) were for 2016, 2017 and 2018 respectively 547.1; 550.3; 532.8 Billion All. In total by destination, agriculture, industry, education etc., etc. for these years was 370; 355 and 338 billion leks. Credit to individuals has increased. This loan does not go directly to the growth of the economy but generally goes in the form of overdrafts or for other destinations that do not increase the enterprises that produce consumption tools and create stable jobs. For the three years 2016, 2017 and 2018, the percentage distribution according to credit destinations has been as shown in Figure 10. 


\section{Journal of International Cooperation and Development}

www.richtmann.org/journal

Vol 2, No 2, November 2019

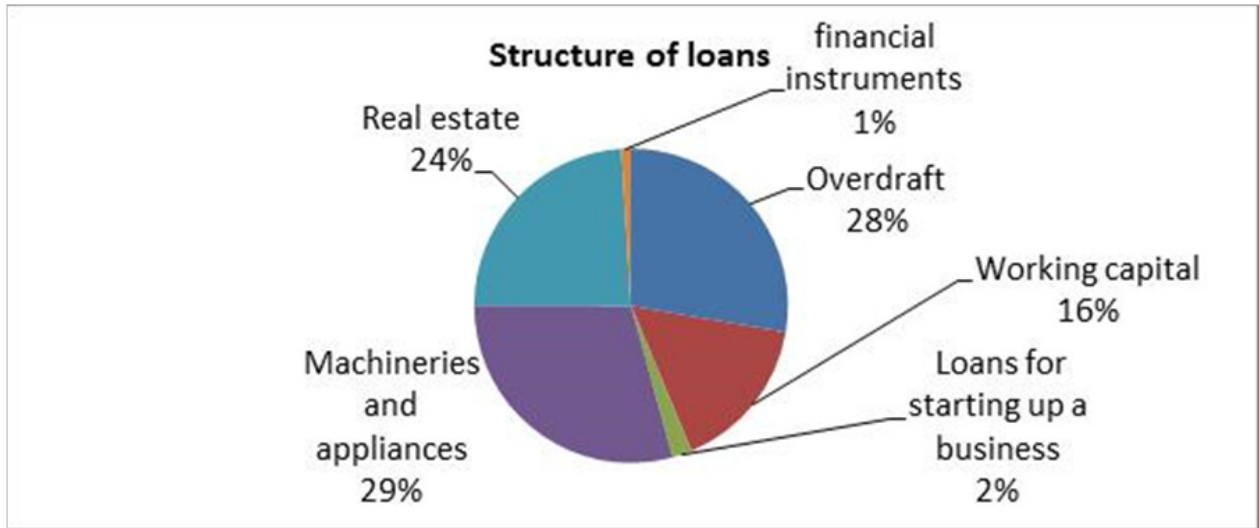

Fig. 10: Private nonfinancial corporate loans by purpose of use and currency

Source: Authors

The data show that the credit has not gone all to capital increase; a large part of it has gone for overdraft, and a part for working capital.

Generally, the overdraft is paid for the payment of employees, due to lack of liquidity.

From the above analysis it is clearly seen that Central Bank policy has not yielded the expected result, in the growth of loans and deposits.

Commercial Banks have not tracked, to the extent possible, Central Bank monetary policy, and often has not been positive in boosting the economy.

The Bank of Albania does not have as its main objective the currency and credit policies, despite the fact that it accounts for Parliament, precisely for exchange rate and credit problems.

The Bank of Albania has its main objective set out in Article 3 of Law No.8269, DATED 23.12.1997 ON THE BANK OF ALBANIA and in Article 4 of its Bank Statute. Article 2, $\mathrm{CB}$ submits to the Assembly a statement containing 4 points.

According to this law, the Bank of Albania submits to the Assembly a Statement of 4 Requests.

In the first request, an assessment is required for the realization of the main objective "achieving and maintaining price stability" for the previous 6 months and the forecasts for the next 6 months.

In the three other requirements, monetary, credit and foreign exchange policy reviews are required for the past 6 months, the next 6 months, and the description of the principles for the next two years. According to this Law, otherwise it is the main objective of the $\mathrm{BQ}$, and otherwise it is the structure of its accountability to Parliament, where the main weight does not occupy the main objective, but there are two problems that are mentioned a bit. They are not even mentioned as secondary targets. The 


\section{Journal of International Cooperation and Development}

www.richtmann.org/journal

Vol 2, No 2, November 2019

analysis shows that in the conditions of the Albanian economy, it is necessary to review the Bank of Albania's main objective. It should be closely linked to the growth of the economy, financial stability and the reduction of the unemployment rate.

\section{Conclusions}

Detailed conclusions are drawn after each topic being analyzed. Overall, we can point out that from the analysis carried out, with a view to determining the effects of monetary policy, its consequences on some of the key macroeconomic indicators, came up with a series of conclusions, of interest to the economy.

From the data of the Statistical Reports of the Central Bank and INSTAT, it was found that the policy of the Central Bank, which has its main objective, "achieving and preserving the level of prices", is applied in the conditions of an unequal monetary market, divided $50 \%$ by $50 \%$ between currency and All. Internal factors and external factors have made the policies applied by the Central Bank to have no transmission effects. Have little or no impact on key macroeconomic indicators. The data showed some of the consequences of the lack of transmission effect: the decrease of the impact on the inflation indicator, the transition of the Albanian economy to the "liquidity trap", the change in the use of deposits in favor of debt instruments, deposits in general and deposits in lek in particular, decrease of purchasing power of deposits, reduction of loans and change of their structure to the detriment of productive investments, etc.

\section{Recommendations}

First, change the main objective of the Central Bank.

Have the main objective, financial stability, currency and credit, in function of economic growth.

In this way the structure of accountability in Parliament will be matched by the Law outlining the objectives of the Central Bank.

Second, create a fully state-owned Trade Bank in order to support the monetary policies and key sectors of the economy.

Competing in the money market like all other entities, with the goal of maximizing profits.

Impact to create a monetary market where there is fair competition, against monopoly, collusion, etc. that affect competition.

This is normal because the first in Albania has state economic entities; secondly, because many countries in the world have positive experience in this regard, they have satisfactory results from a fully state-owned Commercial Bank. 


\section{Journal of International Cooperation and Development}

www.richtmann.org/journal

Vol 2, No 2, November 2019

\section{References}

Angjeli A., Kadriu A., Naqellari A., (2010) MAKROEKONOMIKS . Tiranë; Struge : UMSH press; International University of Struge.

Antonio Santillana del Barrio y Ainhoa Herrarte Sánchez (2012) El Modelo IS-LM, Universidad Autónoma de Madrid.

Bank of Albania. Statistical Report 2008, 2009, 2010, 2011, 2012, 2013, 2014, 2015, 2016, 2017, 2018(III) 2019

Law No.8269, DATE 23.12.1997 "FOR THE BANK OF ALBANIA".

Naqellari A., (2018) Positive Slope Model of Aggregate Demand. Academic Journal of Interdisciplinary Studies, Vol.7, No.3. 2018 Pg. 63-85.

Naqellari A., Dumani N., Hebovia I., (2016) Liquidity trap, the case of Albania. Academic Journal of Interdisciplinary Studies, Vol.5, No.3 November 2016.

Rudinger Dornbuch \& Stanley Fischer (1994). Makroekonomia. International Edition. Tirana 2000.

www.instat.gov.al 